\title{
Comparing Work-Related Correlates of Life Satisfaction for Combat Versus Non-Combat Military Veterans
}

\author{
Gary Blau ${ }^{1} \&$ Glen Miller ${ }^{1}$ \\ ${ }^{1}$ Fox School of Business \& Management, Temple University, Philadelphia, PA, United States \\ Correspondence to: Gary Blau, Human Resource Management Dept. - Fox School of Business \& Management, \\ Alter Hal \#349 (006-00) - 1801 Liacouras Walk, Temple University, Philadelphia, PA 19122, United States. \\ E-mail: gblau@temple.edu
}

Received: September 25, 2020 Accepted: October 30, 2020 Online Published: November 12, 2020

doi:10.5539/jel.v9n6p31 URL: https://doi.org/10.5539/jel.v9n6p31

\begin{abstract}
Military veterans $(n=153)$ completed an on-line survey and were broken down into combat $(n=92)$ versus non-combat $(n=61)$ veterans. The combat veterans had higher life satisfaction, perceived occupational alternatives, and education level versus the non-combat veterans. Looking at correlates to life satisfaction, for both samples number of prior traumatic events (negative) and personal accomplishment (positive) were significantly related. In addition, for the combat veterans, highest education level and perceived occupational alternatives were significantly related to life satisfaction. A high percentage of both combat and non-combat veterans were currently going to school to further their education. Working with employed combat and non-combat veterans, those currently going to school to further their education had higher perceived occupational alternatives than veterans not going back. Working with a smaller group of combat versus non-combat respondents who did volunteer work, the non-combat veterans were higher on perceived meaningfulness of volunteer work than the combat veterans. Returning to school can be one way to help military veterans find rewarding meaningful work, through perceived occupational alternatives, which can help to increase their life satisfaction. If increased education is not an option, volunteer work may also lead to higher perceived meaningful work. As veterans transition from military to civilian life, military out-processing should continue to counsel/prepare transitioning veterans for: finding/interviewing for jobs as well as realistic new careers; identifying meaningful voluntary work opportunities; or finding resources for furthering one's education.
\end{abstract}

Keywords: life satisfaction, combat versus non-combat veterans, going back to school, occupational alternatives

\section{Introduction}

\subsection{Introduce the Problem}

As military veterans transition to civilian life, it is important to understand how well they transition and variables that affect that transition. Morgan et al. (2017) used data from the Pew Research Center's 2011 Veterans Study, which included one-item self-report measures of transition/readjustment to civilian life and happiness. Readjustment to civilian life was measured as, "after your military service would you say that your readjustment to civilian life was, where 1 = very difficult to 4 = very easy." Happiness was measured on a three-point scale, "generally, how would you say things are these days in your life-would you say that you are not too happy (1), happy (2) or very happy (3). Morgan et al. (2017) found that readjustment was a positive correlate to happiness. Recently, a multi-item transition to civilian life scale (TCLS) for military veterans was published (Weiss, Rubin, \& Graeser, 2019) and shows promise for gaining greater insights into this transition process. However, the Weiss et al. (2019) study did not assess prior combat experience in their sample, and combat exposure has been linked to negative outcomes, including higher depression and posttraumatic stress disorder or PSTD (Adams et al., 2019). However, to date there has been little research directly comparing work-related correlates of life satisfaction for combat versus non-combat veteran samples. That was the purpose of this study. Life satisfaction would be expected to be an important component for measuring a successful transition from military to civilian life (Morgan, Desmarais, \& Neupert, 2017). 


\subsection{Measuring Life Satisfaction}

Prior military-related research has investigated life satisfaction as a self-reported outcome. Wang, Harcrow, Spears and Nyutu (2018) studied the relationships of coping skills to life satisfaction for 221 female military spouses. Life satisfaction has been defined as the way a person perceives and evaluates one's life based on self-set standards (Pavot \& Diener, 2008; Pavot, Diener, Colvin, \& Sandvik, 1991). The life satisfaction scale has been successfully used with trauma-related samples, including military (Pavot \& Diener, 2008). Wang et al. (2018) found that avoidance-oriented and task-oriented coping skills had an indirect effect on life satisfaction through their negative relationship with depressive symptoms and positive relationship with positive affect.

\subsection{Work-Related Correlates of Life Satisfaction: Perceived Occupational Alternatives, Meaningful Volunteer Work, and Personal Accomplishment}

Work can affect life satisfaction, for example, Steger, Dik and Duffy (2102) found that meaningful work was positively related to life satisfaction. The TCLS (Weiss et al., 2019) measured "economic well-being" across a number of different dimensions, e.g., housing, education, job, career, and stable personal finances. Thus, work-related items were embedded in a more general scale. A more-focused approach looking at perceived occupational alternatives may be useful. Perceived occupational alternatives is a subjective assessment that given one's background and experience, one can more easily change their occupation (Blau, 2003). Finding alternative work can allow for renewed purpose in life (Scheier et al., 2006), as well as perceived mastery which was positively related to mental health in a study of Canadian military personnel returning from overseas deployment (Lee, Sudom, \& Zamorski, 2013).

It is important to acknowledge that in addition to paid work, volunteer work can be meaningful to an individual. Using non-military samples, Rodell (2013) found that the pull of volunteering can be even stronger when employees perceived less meaning in their current jobs. When working with veterans, meaningful volunteer work should be useful to study since many veterans have the option of not working for an income after their service-based retirement. Meaningful volunteer work may contribute to veterans' life satisfaction.

Personal accomplishment involves feelings of accomplishment and successful achievement in work (Maslach \& Leiter, 1997). Smith et al. (2015) found that greater perceived personal accomplishment was negatively related $(p<.10)$ to depression in 194 U.S. Air Force pararescuemen, i.e., certified paramedics who provide lifesaving medical care under combat conditions. Since depression has been found to be inversely related to life satisfaction (Pavot \& Diener, 2008), it would be expected that personal accomplishment is positively related to life satisfaction.

\section{Prior work comparing combat versus non-combat veteran samples}

Although prior research has not compared combat versus non-combat veteran samples on life satisfaction, other variable comparisons have been made. Schneider, Palmer, Romero and O'Regan (2015, p. 157) defined a traumatic event (TE) as "any accidental man-made disaster (e.g., Chernobyl nuclear power plant disaster), natural disaster (e.g., flood, tornado) or deliberate man-made disaster (e.g., war)." Schneider et al. (2015) suggested that exposure to combat-related versus non-combat related trauma, may have a differential impact. Schneider et al. (2015) used archival data to investigate the impact of a residential rehabilitation treatment program (RRTP) on improvement in PSTD symptom severity and quality of life for two groups: a combat-related trauma group $(\mathrm{n}=28)$ and non-combat related trauma group $(\mathrm{n}=62)$. They found that the RRTP reduced PSTD symptom severity and increased quality of life, regardless of trauma exposure group. Galor and Hentschel (2013) divided Israeli combat and noncombat veterans into PSTD, depression, and control groups and found that the PSTD groups were in the worst psychological state (e.g., highest emotional pain, lack of life satisfaction).

\section{Demographics}

Prior trauma-related studies have assessed the relationships of demographic variables (e.g., race, age, gender, education level) to happiness (Morgan et al., 2017) as well as the time since a traumatic event and number of traumatic events (Adams et al, 2019). Morgan et al. (2017) found education level to be positively related to happiness. Other military-related research has reported age, gender, education level, race, and student status as sample characteristics (Tsai et al., 2015; Weiss et al., 2019).

\subsection{Research Question}

Given the lack of prior research comparing combat versus non-combat veteran samples on life satisfaction, this study asked the following general research question (RQ): Is there a difference in life satisfaction between versus non-combat veterans, and if so, do education level, total number of traumatic events, perceived 
occupational alternatives and personal accomplishment contribute to this difference?

\section{Method}

\subsection{Participants and Procedure}

In the Spring, 2019 a pre-tested Qualtrics survey link was sent out to respondents asking them if they had experienced a past traumatic event (TE), and if so to answer items related to how they experienced this TE. Prior research has suggested there is minimal risk when asking respondents to remember a prior TE (Ferrier-Auerbach, Erbes, \& Polusny, 2009). Respondents were told to skip an item if it was too upsetting to answer. Attention was given to finding military veterans, including those with combat experience. Respondents came from several different sources. One source was the Mid-Atlantic United States (U.S.) University student chapter Veterans' Association. A second source was different contacts the second author had as a military veteran with different U.S.-based veteran-oriented organizations. The survey was anonymous and took approximately 15 minutes to fill out. Once respondents submitted this first survey, they were automatically taken to a separate second survey which was much shorter. This survey asked for an email address so respondents could be randomly selected for either $\$ 50, \$ 20$, or $\$ 10$ multiple gift card drawings. A voluntary consent item was given immediately in the survey, and respondents were asked to not take the survey if they were less than 18 years old. University Institutional Review Board approval was given for this project. Over a period of approximately three months, there were 320 respondents to the first survey, and 269 to the second survey. Unfortunately, 68 (21\%) of the respondents to the first survey had over $90 \%$ missing data and were discarded, leaving a sample of 252 respondents. Within this sample there were $153(61 \%)$ military veterans. This constituted the study sample.

\subsection{Measures}

Combat versus non-combat veteran. Military veteran respondents were asked, "are you a combat veteran?", where $1=$ yes, and $2=$ no.

Most powerful prior traumatic event (TE). A 14 item TE measure was used, asking respondents to pick "the one most powerful traumatic event you have faced either in the line of duty/doing your job, or in a non-work situation. This is the event that you feel had the greatest impact on you." The 14-items used had much overlap with previous TE measures (Schneider et al., 2015; Pietrzak \& Cook, 2013), but given the focus on comparing military combat versus non-combat veterans, had more TE items asking about different military-related situations. In addition, a separate "other" category allowed the respondent to fill in their own most powerful TE if it was not on the list. This measure, separated by combat $(n=92)$ versus non-combat veteran samples $(n=61)$, is reported in Table 1 of the Results section.

Demographic variables. Five demographic variables were asked: gender, where $1=$ male, $2=$ female; race, where 1 = African American, $2=$ American Indian, $3=$ Asian, $4=$ Hispanic, $5=$ Multi-racial, $6=$ Pacific Islander, 7 =White; age, indicated in years; highest education level, where $1=$ high school diploma, to $6=$ doctorate, medical, dental or law degree; and if a respondent was currently going to school to further their education, where $1=$ yes, $2=$ no.

Occupational breakdown of two samples. Respondents were asked, "if you are currently working either part-time (less than 35 hours/week) or full-time (at least 35 hours/week), what occupation best describes your current position?"

Traumatic event variables. Two items were measured. The first asked respondents "if you have experienced more than one trauma category from the above list of 14 categories, please indicate how many trauma categories you have experienced." The response scale was from $1=2$ to $6=$ more than 6 . Responses to this item were added to the initial "most powerful TE" answer to create a "total number of traumatic events" variable used in subsequent data analyses. The second item asked, "how long ago did you face the one most powerful traumatic event you identified above" (in the survey). Responses ranged from $1=$ less than 6 months ago, to $14=$ over 50 years ago. Such retrospection is common in military-focused TE research (Adams et al., 2019; Tsai et al., 2015).

Perceived occupational alternatives. A three-item scale was used (Blau, 2003). Coefficient alpha for the original scale was .93 (Blau, 2003). A sample item was "I would have many options if I decided to change occupations." A seven-point response scale was used, where $1=$ strongly disagree to $7=$ strongly agree. Coefficient alpha for the total sample $(\mathrm{n}=153)=.89$.

Personal accomplishment. A three-item scale was used based on the short-form of the Maslach burnout scale (Maslach \& Leiter, 1997). Coefficient alpha for the original scale was .80 (Maslach \& Leiter, 1997). A sample item is "I feel like I'm positively influencing other people through my work." A seven-point response scale was used, where $1=$ never to $7=$ every day. Coefficient alpha for the total sample $(n=153)=.65$. 
Life satisfaction. A three-item measure was used based on the highest item loadings from the five-item scale in the multi-sample study of Pavot et al. (1991, p. 152). Coefficient alpha for the original scale was .85 (Pavot et al., 1991). A sample item is "the conditions of my life are excellent." A seven-point response scale was used, where $1=$ strongly disagree to $7=$ strongly agree. Coefficient alpha for the total sample $(\mathrm{n}=153)=.92$.

Social desirability response bias (SDRB). A two-item scale based on Paulhus (1984) was used. Coefficient alpha for the original scale was .70 (Paulhus, 1984). SDRB is measured to see the degree to which it is correlated with other study variables. A higher correlation suggests that respondents may not be giving truthful answers (Paulhus, 1984). A sample item is "I am always willing to admit it when I make a mistake." A seven-point response scale was used, where $1=$ strongly disagree to $7=$ strongly agree. Coefficient alpha for the total sample $(\mathrm{n}=153)$ $=.52$.

Perceived meaningfulness of volunteer work. A three-item measure was used, adapted from Steger et al. (2012). Coefficient alpha for the original scale was .93 (Steger et al., 2012). A sample item is "My volunteer work contributes to my personal growth." A seven-point response scale was used, where $1=$ strongly disagree to $7=$ strongly agree. Coefficient alpha for this total sample $(n=64)=.94$.

\subsection{Data Analyses}

All data were analyzed using SPSS-PC version 24 (SPSS, 2013). All data analyses compared the combat versus non-combat veteran samples. Frequency breakdowns were done for most powerful TE, demographic variables and occupational category. Means, standard deviations and correlations between continuous variables were calculated. Listwise deletion of data was used for all analyses. In this method, if a variable has missing data, the entire case is excluded from further analyses (Roth, 1994). This resulted in some additional missing data. Independent sample t-tests were used to compare the variable means for combat versus non-combat veterans. Fisher's r-to-z transformation was used to test the significance of the difference between correlations for the combat versus non-combat veterans. Independent samples t-tests were also used to compare smaller sub-samples on going back to school to further one's education and perceived meaningfulness of volunteer work. Given the small sample sizes being compared, $p<.10$ (two-tailed) was used as the cutoff for statistical significance. Hopkins, Marshall, Batterham and Hanin (2008, p. 6) have argued that $p=.10$, with a $90 \%$ confidence is "an appropriate default level of confidence."

\section{Results}

\subsection{Most Powerful TE, Demographic, and Occupational Breakdown by Sample}

Results are broken down comparing combat versus non-combat veteran samples. Looking at the most powerful TE (Table 1), the highest frequency specific TE frequency for the combat veteran sample was "seeing a comrade/fellow soldier killed/severely wounded," $n=33,36 \%$; while for the non-combat veteran sample the highest frequency specific TE is was "non-work: experiencing personal domestic violence/sexual assault/physical abuse," $\mathrm{n}=10,17 \%$. 
Table 1. Most powerful type of traumatic event by Combat versus Non-combat Veteran Samples

\begin{tabular}{lll}
\hline Most Powerful Traumatic Event Faced & $\begin{array}{l}\text { Combat Veteran } \\
\text { Sample }(\mathrm{n}=92)\end{array}$ & $\begin{array}{l}\text { Non-combat Veteran } \\
\text { Sample }(\mathrm{n}=61)\end{array}$ \\
\hline Killing/severely wounding enemy soldiers & $\mathrm{n}=10(11 \%)$ & $\mathrm{n}=0$ \\
Killing/severely wounding civilians & $\mathrm{n}=2(2 \%)$ & $\mathrm{n}=0$ \\
Seeing a comrade/fellow soldier killed/severely wounded & $\mathrm{n}=33(36 \%)$ & $\mathrm{n}=5(8 \%)$ \\
Being severely wounded/injured in combat & $\mathrm{n}=7(8 \%)$ & $\mathrm{n}=0$ \\
Killing/severely wounding someone committing a crime & $\mathrm{n}=0$ & $\mathrm{n}=0$ \\
Seeing a work colleague killed/severely wounded & $\mathrm{n}=4(4 \%)$ & $\mathrm{n}=2(3 \%)$ \\
Seeing a civilian(s) killed/severely injured during a crime scene, fire or accident & $\mathrm{n}=6(7 \%)$ & $\mathrm{n}=9(15 \%)$ \\
Suffering a serious personal work-related injury/accident (being unable to work) & $\mathrm{n}=1(1 \%)$ & $\mathrm{n}=1(2 \%)$ \\
Seeing a work colleague suffer a serious work-related injury/accident (being unable to & $\mathrm{n}=0$ & $\mathrm{n}=0$ \\
work) & & $\mathrm{n}=6(10 \%)$ \\
Non-work: violent death of a family member (e.g., spouse, parent, child)/close friend, & $\mathrm{n}=4(4 \%)$ & $\mathrm{n}=7(12 \%)$ \\
including suicide and drug overdose & & $\mathrm{n}=5(8 \%)$ \\
Non-work: non-violent death (e.g., illness, accident, natural disaster) of a family & $\mathrm{n}=4(4 \%)$ & $\mathrm{n}=10(17 \%)$ \\
member/close friend & $\mathrm{n}=4(4 \%)$ & $\mathrm{n}=2(3 \%)$ \\
Non-work: serious personal illness/injury/accident & $\mathrm{n}=0$ & $\mathrm{n}=14(23 \%)$ \\
Non-work: experiencing personal domestic violence/sexual assault/physical abuse & $\mathrm{n}=1(1 \%)$ & $\mathrm{n}=3(5 \%)$ \\
Non-work: witnessing domestic violence/sexual assault/physical abuse & $\mathrm{n}=16(17 \%)$ & $\mathrm{n}=2(3 \%)$ \\
Other - list (biggest listings) & $\mathrm{n}=3(3 \%)$ & $\mathrm{n}=0$ \\
Sexual assault in military & $\mathrm{n}=3(3 \%)$ & $\mathrm{n}=3(5 \%)$ \\
Work harassment/abuse/discrimination & $\mathrm{n}=4(4 \%)$ & $\mathrm{n}=2(3 \%)$ \\
Survivors' guilt & $\mathrm{n}=0$ & $\mathrm{n}=0$ \\
Personal injury, e.g., not in combat & & \\
Living in alcoholic household & & \\
\hline
\end{tabular}

Table 2 shows the demographic breakdown for the two samples. Both samples were male-dominated and predominantly White. Age was reported in years but is collapsed into categories to save space in the table. The age group $33-39, \mathrm{n}=28,(30 \%)$ was the highest frequency category for the combat sample while it was 26-32 for the non-combat sample, $\mathrm{n}=13(21 \%)$. For both samples, a four-year degree was the highest education level frequency category. A high percentage of both combat $(\mathrm{n}=59,64 \%)$ and non-combat $(\mathrm{n}=45,74 \%)$ respondents were going to school to further their education. 
Table 2. Frequency statistics for demographic variables - Combat and Non-combat Veteran Samples

\begin{tabular}{|c|c|c|}
\hline Variable & Combat Sample $(\mathrm{n}=92)$ & Non-combat Sample $(\mathrm{n}=61)$ \\
\hline \multicolumn{3}{|l|}{ Gender } \\
\hline Male & $\mathrm{n}=81(88 \%)$ & $\mathrm{n}=43(71 \%)$ \\
\hline Female & $\mathrm{n}=11(12 \%)$ & $\mathrm{n}=17(27 \%)$ \\
\hline Did not identify & $\mathrm{n}=0$ & $\mathrm{n}=1(2 \%)$ \\
\hline \multicolumn{3}{|l|}{ Race } \\
\hline African American & $\mathrm{n}=5(5 \%)$ & $\mathrm{n}=7(11 \%)$ \\
\hline American Indian & $\mathrm{n}=0$ & $\mathrm{n}=0$ \\
\hline Asian & $\mathrm{n}=5(5 \%)$ & $\mathrm{n}=2(3 \%)$ \\
\hline Hispanic & $\mathrm{n}=5(5 \%)$ & $\mathrm{n}=3(5 \%)$ \\
\hline Multi-racial & $\mathrm{n}=8(9 \%)$ & $\mathrm{n}=6(10 \%)$ \\
\hline Pacific Islander & $\mathrm{n}=0$ & $\mathrm{n}=0$ \\
\hline White & $\mathrm{n}=69(75 \%)$ & $\mathrm{n}=43(71 \%)$ \\
\hline \multicolumn{3}{|l|}{ Age (collapsed into categories for space) } \\
\hline $19-25$ & $\mathrm{n}=3(3 \%)$ & $\mathrm{n}=11(18 \%)$ \\
\hline $26-32$ & $\mathrm{n}=17(19 \%)$ & $\mathrm{n}=13(21 \%)$ \\
\hline $33-39$ & $\mathrm{n}=28(30 \%)$ & $\mathrm{n}=7(11 \%)$ \\
\hline $40-46$ & $\mathrm{n}=6(7 \%)$ & $\mathrm{n}=8(13 \%)$ \\
\hline $47-53$ & $\mathrm{n}=13(14 \%)$ & $\mathrm{n}=5(8 \%)$ \\
\hline $54-60$ & $\mathrm{n}=3(3 \%)$ & $\mathrm{n}=2(3 \%)$ \\
\hline $61-67$ & $\mathrm{n}=2(2 \%)$ & $\mathrm{n}=4(7 \%)$ \\
\hline $68-74$ & $\mathrm{n}=15(16 \%)$ & $\mathrm{n}=9(15 \%)$ \\
\hline 75 or more & $\mathrm{n}=5(5 \%)$ & $\mathrm{n}=1(2 \%)$ \\
\hline \multicolumn{3}{|l|}{ Highest Education Level } \\
\hline High School Diploma & $\mathrm{n}=1(1 \%)$ & $\mathrm{n}=2(3 \%)$ \\
\hline Some College & $\mathrm{n}=7(8 \%)$ & $\mathrm{n}=14(23 \%)$ \\
\hline Associate Degree & $\mathrm{n}=10(11 \%)$ & $\mathrm{n}=5(8 \%)$ \\
\hline Four Year Degree & $\mathrm{n}=35(38 \%)$ & $\mathrm{n}=20(33 \%)$ \\
\hline Masters Degree & $\mathrm{n}=28(30 \%)$ & $\mathrm{n}=14(23 \%)$ \\
\hline Doctorate, Medical, Dental or Law Degree & $\mathrm{n}=11(12 \%)$ & $\mathrm{n}=6(10 \%)$ \\
\hline \multicolumn{3}{|l|}{$\begin{array}{l}\text { Are you currently going to school to further your } \\
\text { education }\end{array}$} \\
\hline Yes & $\mathrm{n}=59(64 \%)$ & $\mathrm{n}=45(74 \%)$ \\
\hline No & $\mathrm{n}=33(36 \%)$ & $\mathrm{n}=15(24 \%)$ \\
\hline Missing & & $\mathrm{n}=1(2 \%)$ \\
\hline
\end{tabular}

For occupational breakdown (Table 3), of the 153 respondents, 99 (65\%) were currently working in some type of paid position. Thirty-two (21\%) respondents said they had retired, and twenty-two (14\%) indicated they were not currently working. A further breakdown of the 99 employed respondents indicated that $60(61 \%)$ were combat veterans and 39 (39\%) were non-combat veterans. Table 3 shows the occupational breakdown of these two different samples, including an "other," category which could be filled in.

The highest specific category frequency for the combat veteran sample was "other physical health-related professions (e.g., doctor, nurse, medical technologist)," while for the non-combat veteran sample it was "education-related profession (e.g., teacher, school counselor, administrative)." In addition, 64 of the 153 respondents (42\%) indicated that they were involved in some type of volunteer work. 
Table 3. Occupational frequency breakdown of currently working Combat versus Non-combat Veteran Samples

\begin{tabular}{|c|c|c|}
\hline Occupational Category- Frequency & Combat Sample $(\mathrm{n}=60)$ & Non-combat Sample $(\mathrm{n}=39)$ \\
\hline Fire Fighter & $\mathrm{n}=1(2 \%)$ & $\mathrm{n}=0$ \\
\hline Police Officer & $\mathrm{n}=3(5 \%)$ & $\mathrm{n}=3(8 \%)$ \\
\hline First Responder (e.g., EMT, Paramedic) & $\mathrm{n}=0$ & $\mathrm{n}=0$ \\
\hline Other Physical Health-related Professions & $\mathrm{n}=7(12 \%)$ & $\mathrm{n}=2(5 \%)$ \\
\hline (e.g., doctor, nurse, medical technologist) & & \\
\hline Mental/Spiritual Health Profession (e.g., psychologist, clergy) & $\mathrm{n}=4(7 \%)$ & $\mathrm{n}=2(5 \%)$ \\
\hline $\begin{array}{l}\text { Education-related Profession (e.g., teacher, school counselor, } \\
\text { administrative) }\end{array}$ & $\mathrm{n}=4(7 \%)$ & $\mathrm{n}=11(28 \%)$ \\
\hline $\begin{array}{l}\text { Financial Services-related Profession (e.g., banking, } \\
\text { insurance, financial planning) }\end{array}$ & $\mathrm{n}=1(2 \%)$ & $\mathrm{n}=1(3 \%)$ \\
\hline $\begin{array}{l}\text { Information Technology (e.g., computer analyst, data } \\
\text { processing specialist) }\end{array}$ & $\mathrm{n}=3(5 \%)$ & $\mathrm{n}=1(3 \%)$ \\
\hline Government and Public Administration & $\mathrm{n}=5(8 \%)$ & $\mathrm{n}=2(5 \%)$ \\
\hline Hospitality or Customer Service-related (including retail sales) & $\mathrm{n}=1(2 \%)$ & $\mathrm{n}=1(3 \%)$ \\
\hline Manufacturing-related & $\mathrm{n}=5(8 \%)$ & $\mathrm{n}=0$ \\
\hline Legal Services (e.g., lawyer, legal aid) & $\mathrm{n}=2(3 \%)$ & $\mathrm{n}=0$ \\
\hline $\begin{array}{l}\text { Construction-related (e.g., engineering building, maintenance, } \\
\text { repair) }\end{array}$ & $\mathrm{n}=3(5 \%)$ & $\mathrm{n}=3(8 \%)$ \\
\hline Transportation-related (commercial, private) & $\mathrm{n}=0$ & $\mathrm{n}=0$ \\
\hline Entertainment (e.g., sports, media) & $\mathrm{n}=0$ & $\mathrm{n}=2(5 \%)$ \\
\hline Human Resources & $\mathrm{n}=1(2 \%)$ & $\mathrm{n}=0$ \\
\hline Other - list (biggest listings) & $\mathrm{n}=20(33 \%)$ & $\mathrm{n}=11(28 \%)$ \\
\hline Active duty military & $\mathrm{n}=4(7 \%)$ & $\mathrm{n}=0$ \\
\hline Army/National Guard Reserves & $\mathrm{n}=3(5 \%)$ & $\mathrm{n}=2(5 \%)$ \\
\hline Consultant-related/Life skills coach & $\mathrm{n}=0$ & $\mathrm{n}=1(3 \%)$ \\
\hline Graduate student/student worker & $\mathrm{n}=0$ & $\mathrm{n}=2(5 \%)$ \\
\hline Health-care/Medical sales & $\mathrm{n}=0$ & $\mathrm{n}=2(5 \%)$ \\
\hline Management/Office administration & $\mathrm{n}=0$ & $\mathrm{n}=2(5 \%)$ \\
\hline Military-related (e.g., consultant, workshops) & $\mathrm{n}=3(5 \%)$ & $\mathrm{n}=0$ \\
\hline
\end{tabular}

\subsection{Correlation and T-Test Analyses}

Table 4 shows the means, standard deviations and correlations for the continuously measured variables broken down for each sample. Using listwise deletion there was a further reduction in sample size for each sample. Comparing the variables between samples, there were three sample differences. The combat sample $(M=5.36$, $S D=1.13)$ had a higher overall education level versus the non-combat sample $(M=4.86, S D=1.52), t(86)=$ $1.86, p<.10$ (two-tailed). The combat sample had higher perceived occupational alternatives $(M=5.31, S D=$ $1.73)$ versus the non-combat sample $(M=4.53, S D=2.05), t(86)=1.96, p<.05$ (two-tailed). Finally, the combat sample had higher life satisfaction $(M=5.46, S D=1.26)$ versus the non-combat sample $(M=4.85, S D$ $=1.29$ ), $t(86)=2.29, p<.05$ (two-tailed).

Looking at the correlations to life satisfaction, both samples had a significant negative correlation of number of traumatic events to life satisfaction, i.e., $r(54)=-.31, p<.05$, for the combat veterans, and $r(35)=-.39, p<.05$, for the non-combat veterans. Both samples had a significant positive correlation of personal accomplishment to life satisfaction, i.e., $r(54)=.36, p<.01$, for the combat veterans, and $r(35)=.34, p<.05$, for the non-combat veterans. Although not a statistically significant correlational difference, the combat sample had a significant positive correlation of highest education level to life satisfaction, $r(54)=.44, p<.01$, while the correlation for these two variables for the non-combat sample was not significant, $r(35)=.21, p>.05$. A second correlational difference, not statistically significant, was that the combat sample had a significant positive correlation of perceived occupational alternatives to life satisfaction, $r(54)=.39, p<.01$, but the correlation for these two variables for the non-combat sample was not significant, $r(35)=.25, p>.05$. 
Table 4. Means, standard deviations, and correlations for continuous variables for currently working veterans

\begin{tabular}{|c|c|c|c|c|c|c|c|c|c|c|c|}
\hline \multirow[b]{2}{*}{ Measure } & \multicolumn{2}{|c|}{$\begin{array}{l}\text { Combat Veterans } \\
(\mathrm{n}=56)\end{array}$} & \multicolumn{2}{|c|}{$\begin{array}{l}\text { Non-combat } \\
\text { Veterans }(\mathrm{n}=37)\end{array}$} & \multirow[b]{2}{*}{1} & \multirow[b]{2}{*}{2} & \multirow[b]{2}{*}{3} & \multirow[b]{2}{*}{4} & \multirow[b]{2}{*}{5} & \multirow[b]{2}{*}{6} & \multirow[b]{2}{*}{7} \\
\hline & $\mathrm{M}$ & SD & $\mathrm{M}$ & $\mathrm{SD}$ & & & & & & & \\
\hline 1. $\mathrm{Age}^{\mathrm{a}}$ & 34.47 & 10.54 & 31.51 & 14.36 & $(--)$ & $.63^{* *}$ & -.16 & $.61^{* *}$ & -.12 & .12 & .24 \\
\hline 2. Highest Education Level ${ }^{b}$ & $5.36^{\mathrm{g}}$ & 1.13 & $4.86^{\mathrm{g}}$ & 1.52 & .20 & $(---)$ & -.20 & $.55^{* *}$ & -.01 & .26 & .21 \\
\hline $\begin{array}{l}\text { 3. Total Number of } \\
\text { Traumatic Events }\end{array}$ & 3.43 & 2.04 & 3.00 & 2.03 & -.25 & .15 & $(---)$ & -.01 & -.11 & $-.31+$ & $-.39 *$ \\
\hline $\begin{array}{l}\text { 4. How Long Ago Most } \\
\text { Powerful Traumatic Event }\end{array}$ & 5.42 & 2.41 & 4.77 & 2.50 & $.51^{* *}$ & -.14 & $-.26+$ & $(---)$ & -.23 & -.02 & .15 \\
\hline $\begin{array}{l}\text { 5. Perceived Occupational } \\
\text { Alternatives }^{\mathrm{e}}\end{array}$ & $5.31^{\mathrm{h}}$ & 1.73 & $4.53^{\mathrm{h}}$ & 2.05 & -.08 & .21 & -.17 & -.16 & $(---)$ & $.28+$ & .25 \\
\hline 6. Personal Accomplishment ${ }^{f}$ & 5.47 & 1.40 & 5.07 & 1.54 & .15 & .13 & .01 & -.14 & .12 & $(---)$ & $.34 *$ \\
\hline 7. Life Satisfaction ${ }^{\mathrm{e}}$ & $5.46^{\mathrm{i}}$ & 1.26 & $4.85^{\mathrm{i}}$ & 1.29 & .20 & $.44 * *$ & $-.31 *$ & .01 & $.39 * *$ & $.36^{* *}$ & $(---)$ \\
\hline
\end{tabular}

Note. $\mathrm{p}<.05 ;{ }^{* *} \mathrm{p}<.01$ (two-tailed). Combat veteran sample correlations are below the diagonal (----), non-combat veteran sample correlations are above the diagonal.

${ }^{a}$ Age, measured in years

${ }^{\mathrm{b}}$ Highest Education Level, 1 = Some high School, $2=$ High school diploma/G.E.D., $3=$ some college, $4=$ Associates degree, $5=$ Baccalaureate ( 4 year) degree, $6=$ Masters degree, $7=$ doctorate, medical, dental or law degree

${ }^{\mathrm{c}}$ Total Number of Traumatic Events, $1=1,2=2,3=3,4,=4,5,=5,6=6,7=$ more than 6

${ }^{\mathrm{d}}$ How Long Ago Most Powerful Traumatic Event, where $1=$ less than 6 months ago, $2=6$ months to 1 year, $3=1$ to 2 years, $4=3$ to 5 years, $5=6$ to 10 years, $6=11$ to 15 years, $7=16$ to 20 years, $8=21$ to 25 years, $9=26$ to 30 years, $10=31$ to 35 years, $11=36$ to 40 years $12=$ 41 to 45 years, $13=46$ to 50 years, $14=$ over 50 years

${ }^{\mathrm{e}}$ Perceived Occupational Alternatives, Life Satisfaction, $1=$ strongly disagree, $2=$ disagree, $3=$ slightly disagree, $4=$ neither agree nor disagree, $5=$ slightly agree, $6=$ agree, $7=$ strongly agree

${ }^{\mathrm{f}}$ Personal Accomplishment, 1 = never, 2 = a few times a year, $3=$ once a month or less, $4=$ a few times a month, $5=$ once a week, $6=\mathrm{a}$ few times a week 7 = every day

${ }^{\mathrm{g}}$ Significant difference, Highest Education level, $t(86)=1.86, p<.10$ (two-tailed)

${ }^{\mathrm{h}}$ Significant difference, Perceived Occupational Alternatives, $t(86)=1.96, p<.05$ (two-tailed)

${ }^{\mathrm{i}}$ Significant difference, Life Satisfaction, $t(86)=2.29, p<.05$ (two-tailed).

In addition, race was recoded into two groups (White, Non-white) for both samples, and neither race nor gender had a significant relationship to life satisfaction for either sample. Also, there were no significant relationships of social desirability response bias to life satisfaction for either sample. Working with the smaller group of respondents $(\mathrm{n}=64)$ who did volunteer work, 38 were in the combat sample and 26 in the non-combat sample. An independent samples t-test on perceived meaningfulness of volunteer work showed that the non-combat subsample $(M=6.50, S D=.74)$ had a higher mean on perceived meaningfulness than the combat subsample ( $M$ $=5.77, S D=1.27), t(62),=2.62, p<.05$ (two-tailed). Working with combined employed combat and non-combat veterans, there was a significant difference in perceived occupational alternatives such that those going back to school $(\mathrm{n}=78)$ had a higher mean on perceived alternatives $(M=5.06, S D=1.91)$ than those not going back to school $(\mathrm{n}=21), M=4.27, S D=1.94, t(97)=1.68, p<.10$ (two-tailed). Finally, additional follow-up analyses showed that veterans $(\mathrm{n}=101)$ who had faced a more recent powerful traumatic event $M=$ 4.73, (approximately six years ago), $S D=2.04$ were more likely to be going back to school versus veterans $(\mathrm{n}=$ 48) whose traumatic event was longer ago, $M=8.46$ (approximately 25 years ago), $S D=3.97, t(59.16)=-3.73$, $p<.01$ (two-tailed) .

\section{Discussion}

To the authors' knowledge, this is one of the first studies to compare work-related correlates of life satisfaction for combat versus non-combat veterans. The results found were interesting but in need of further validation. Looking at mean differences between continuous variables, the combat veterans self-reported an overall higher education level, higher perceived occupational alternatives, and higher life satisfaction, versus the non-combat veterans. Both samples reported significant relationships of number of TEs (negative) and personal accomplishment (positive) to life satisfaction. Only for the combat veterans were there positive relationships of highest education level and perceived occupational alternatives to life satisfaction. Overall, these main study results suggest that work-related variables are important for understanding military veterans' life satisfaction.

Prior research, with non-military samples, has shown that finding alternative work can allow for a renewed purpose in life (Scheier et al., 2006). Personal accomplishment, which includes feeling that one is positively influencing others through one's work, can be one way for veterans to counteract loneliness which can lead to 
depression (Martin \& Hartley, 2017). Such work can be paid or voluntary. In this study, higher meaningfulness of volunteer work was stronger for smaller subsets of the non-combat versus combat samples. Tsai, El-Gabalawy, Sledge, Southwick and Pietrzak (2015) found that volunteering was positively related to posttraumatic growth in a survey of 3,157 US veterans. Volunteering can be even stronger when employees perceived less meaning in their jobs (Rodell, 2013). These combined results suggest that finding meaningful work, either paid or volunteer, may be important to both combat and non-combat veterans as they transition back to civilian life.

Increased education can be one way to help military veterans find rewarding meaningful work to help to increase their life satisfaction (Morgan et al., 2017), as well as help to reintegrate veterans into their communities (Ellison, Reilly, Mueller, Schultz, \& Drebing, 2018). In a qualitative study, Bagby, Barnard-Brak, Thompson and Sulak (2015) found the university-related educational experiences of 11 student veterans helpful as they transitioned from military to civilian life. In this study, veterans going back to school to further their education perceived higher occupational alternatives than those not going back to school. Veterans who had a more recent powerful traumatic event were more likely to be going back to school than veterans whose traumatic event was longer ago. University stakeholders need to be sensitive to helping military veterans successfully transition back into education, including student organizations, faculty, and administration (Bagby et al., 2015), as well as utilizing veteran peers where possible (Ellison et al., 2018). Academic resources, such as a university-based student veterans association, may be particularly important to continue prior experienced camaraderie for transitioning veterans (Bagby et al., 2015).

\subsection{Limitations and Future Research}

A shortened version of the life satisfaction measure was used. Another limitation is the small sample size for both combat and non-combat veterans, especially when using only those currently working, or doing volunteer work. This reduced the power to detect statistically significant differences between the two samples, and also did not allow for more sophisticated statistical analyses, such as regression (Stevens, 1996). In our opinion, unless one has access to large data sets, e.g., Pew Research Center (Morgan et al., 2017), National Health and Resilience in Veterans Study (Tsai et al., 2015), or outpatients at a multihospital system (Adam et al., 2019), it can be very challenging to find combat veterans as well as non-veterans willing to fill out a survey. A limitation for the combat veteran sample is that we did not gather details on deployment.

In addition, the self-report, cross-sectional research design of this study does not allow for causal inferences, and method variance is a general concern. However, in our study a one-factor test (Podsakoff, MacKenzie, Lee, \& Podsakoff, 2003) showed that, using all variable items in a principal components analysis (PCA), there were six factors with eigenvalues of at least 1.0 extracted via PCA, and the first factor accounted for $24 \%$ of the variance. If this first factor represents common method variance, it is not an overriding limitation. In addition, social desirability response bias (Paulhus, 1984) was not strongly related to other study variables suggesting that full-data respondents gave truthful answers. We lost $21 \%$ of our sample due to over $90 \%$ missing data. We believe that was mainly a function of the economic incentive offered, i.e., the common pattern of answering only the first few items to then be entered into the multiple gift card drawings. A final limitation was that two scales, personal accomplishment and social desirability response bias, had reliability estimates below the recommended threshold of .70 (Nunnally, 1978). Future research using other samples of combat and non-combat veterans is needed to test the generalizability of these initial findings. One area for future research would be to examine the careers that veterans pursue after transitioning to civilian life, for example does trauma keep veterans away from service-oriented careers? Another area for future research would be to examine the role of moral injury as a variable impacting life satisfaction (Dursun \& Watkins, 2018).

\subsection{Conclusion}

The results across both combat and non-combat veteran samples support personal accomplishment as a positive correlate for life satisfaction. Finding meaningful work, either through perceived occupational alternatives, or volunteering, is important to veterans. Education can be one means to help veterans perceive greater occupational alternatives. Veterans who had a more recent powerful traumatic event were more likely to be going back to school than veterans whose traumatic event was longer ago. As veterans transition back to civilian life, military out-processing should continue to counsel/prepare transitioning veterans on finding/interviewing for jobs as well as identifying realistic new careers. If not paid work, what type of volunteer work would a transitioning veteran find meaningful and how can he or she prepare for this? If a potential new career requires additional education, what resources are available to help the transitioning veteran get this education? Answering these questions will increase the probability of a successful transition (Weiss et al., 2019). We hope this study stimulates continued research on investigating work-related correlates of life satisfaction for veterans, leading to 
useful/impactful solutions.

\section{References}

Adams, R. E., Urosevich, T. G., Hoffman, S. N., Kirchner, H. L., Figley, C. R., Withey, C. A., ... Boscarino, J. A. (2019). Social and psychological risk and protective factors for veteran well-being: The role of veteran identity and its implications for intervention. Military Behavioral Health, 7(3), 304-314. https://doi.org/10.1080/21635781.2019.1580642

Bagby, J. H., Barnard-Brak, L., Thompson, L. W., \& Sulak, T. N. (2015). Is anyone listening? An ecological systems perspective on veterans transitioning from the military to academia. Military Behavioral Health, 3(4), 219-229. https://doi.org/10.1080/21635781.2015.1057306

Blau, G. (2003). Testing a four-dimensional structure of occupational commitment. Journal of Occupational and Organizational Psychology, 76, 469-488. https://doi.org/10.1348/096317903322591596

Dursun, S., \& Watkins, K. (2018). Moral injury: What we know and what we need to know. Military Behavioral Health, 6(2), 121-126. https://doi.org/10.1080/21635781.2018.1454365

Ellison, M. L., Reilly, E. D., Mueller, L., Schultz, M. R., \& Drebing, C. E. (2018). A supported education service pilot for returning veterans with posttraumatic stress disorder. Psychological Services, 15(2), 200-207. https://doi.org/10.1037/ser0000180

Ferrier-Auberach, A. G., Erbes, C. R., \& Polusny, M. A. (2009). Does trauma survey research cause more distress than other types of survey research? Journal of Traumatic Stress, 22(4), 320-323. https://doi.org/10.1002/jts.20416

Galor, S., \& Hentschel, U. (2013). PSTD and depression among combat and noncombat Israeli veterans. Military Behavioral Health, 1, 159-166. https://doi.org/10.1080/21635781.2013.839323

Hopkins, W. G., Marshall, S. W., Batterham, A. M., \& Hanin, J. (2008). Progressive statistics for studies in sports medicine and exercise science. Medicine \& Science in Sports \& Exercise, 40, 1-10. https://doi.org/10.1249/MSS.0b013e31818cb278

Lee, J. E. C., Sudom, K. A., \& Zamorski, M. A. (2013). Longitudinal analysis of psychological resilience and mental health in Canadian military personnel returning from overseas deployment. Journal of Occupational Health Psychology, 18(3), 327-337. https://doi.org/10.1037/a0033059

Martin, J. C., \& Hartley, S. L. (2017). Lonely, stressed and depressed: The impact of isolation on U.S. Veterans. Military Behavioral Health, 5(4), 384-392. https://doi.org/10.1080/21635781.2017.1333064

Maslach, C., \& Leiter, M. P. (1997). The truth about burnout: How organizations cause personal stress and what to do about it. San Francisco, CA: Jossey-Bass.

Morgan, J. K., Desmarais, S. L., \& Neupert, S. D. (2017). An integrated model of health and happiness among post-9/11 military veterans. Military Behavioral Health, 5(3), 236-244. https://doi.org/10.1080/21635781.2017.1310681

Nunnally, J. (1978). Psychometric theory (2nd ed.). New York, NY: McGraw Hill.

Paulhus, D. (1984), Two-component models of socially desirable responding. Journal of Personality and Social Psychology, 43(4), 838-852. https://doi.org/10.1037/0022-3514.46.3.598

Pavot, W., \& Diener, E. (2008). The satisfaction with life scale and the emerging construct of life satisfaction. The Journal of Positive Psychology, 3(2), 137-152. https://doi.org/10.1080/17439760701756946

Pavot, W., Diener, E., Colvin, C. R., \& Sandvik, E. (1991). Further validation of the satisfaction with life scale: Evidence for the cross-method convergence of well-being measures. Journal of Personality Assessment, 57(1), 149-161. https://doi.org/10.1207/s15327752jpa5701_17

Pietrzak, R. H., \& Cook, J. M. (2013). Psychological resilience in older U.S. veterans: Results from the National Health and Resilience in Veterans Study. Depression and Anxiety, 30, 432-443. https://doi.org/10.1002/da.22083

Podsakoff, P., Mackenzie, S., Lee, J., \& Podsakoff, N. (2003). Common method biases in behavioral research: Critical review of the literature and recom mended remedies. Journal of Applied Psychology, 88(5), 879-903. https://doi.org/10.1037/0021-9010.88.5.879

Rodell, J. A. (2013). Finding meaning through volunteering: Why do employees volunteer and what does it mean for their jobs? Academy of Management Journal, 56(5), 1274-1294. 
https://doi.org/10.5465/amj.2012.0611

Roth, P. L. (1994). Missing data: A conceptual review for applied psychologists. Personnel Psychology, 47, 537-560. https://doi.org/10.1111/j.1744-6570.1994.tb01736.x

Scheier, M. F., Wrosch, C., Baum, A., Cohen, S., Maartire, L. M., Matthews, K. A., ... Zdaniuk, B. (2006). The Life Engagement Test: Assessing purpose in life. Journal of Behavioral Medicine, 29(3), 291-298. https://doi.org/10.1007/s10865-005-9044-1

Schneider, B. P., Palmer, G. A., Romero, R., \& O'Regan, J. (2015). Post-traumatic stress disorder and quality-of-life outcomes of veterans seeking treatment in a residential rehabilitation treatment program. Military Behavioral Health, 3, 157-166. https://doi.org/10.1080/21635781.2015.1009215

Smith, H. A., Stephenson, J. A., Morrow, C. E., Haskell, J. S., Staal, M., Bryan, A. O., \& Bryan, C. J. (2015). Factors associated with burnout among active duty versus National Guard/Reserve U. S. Air Force pararescuemen. Military Behavioral Health, 3(1), 5-13. https://doi.org/10.1080/21635781.2014.995245

SPSS-PC (version 24). (2015). Statistical package for the social sciences. Chicago: IBM Corp.

Steger, M. F., Dik, B. J., \& Duffy, R. D. (2012). Measuring meaningful work: The Work and Meaning Inventory (WAMI). Journal of Career Assessment, 20(3), 322-337. https://doi.org/10.1177/1069072711436160

Stevens, J. (1996). Applied multivariate statistics for the social sciences (2nd ed.). Mahwah, NJ: Lawrence Erlbaum.

Tsai, J., El-Gabalawy, R., Sledge, W. H., Southwick, S. M., \& Pietrzak, R. H. (2015). Posttraumatic growth among veterans in the USA: Results from the National Health and Resilience in Veterans Study. Psychological Medicine, 45, 165-179. https://doi.org/10.1017/S0033291714001202

Wang, M.-C., Harcrow, A.-M., Spears, A., \& Nyutu, P. (2018). Affect, coping, and satisfaction with life among military spouses. Military Behavioral Health, 6(4), 346-354. https://doi.org/10.1080/21635781.2018.1490225

Weiss, E. L., Rubin, A., \& Graeser, M. (2019). Transitioning to civilian life scale (TCLS): Development, reliability, and validity. Military Behavioral Health, 7(1), 57-63. https://doi.org/10.1080/21635781.2018.1540317

\section{Copyrights}

Copyright for this article is retained by the author, with first publication rights granted to the journal.

This is an open-access article distributed under the terms and conditions of the Creative Commons Attribution license (http://creativecommons.org/licenses/by/4.0/). 